\title{
11 Crop improvement for agricultural transformation in Southern Africa
}

\author{
Hussein Shimelis, E. T. Gwata and Mark D. Laing
}

\section{Introduction}

Crop genetic improvement is one of the strategies for transforming African agriculture to meet the demand for food, feed and bioenergy. Plant breeding can deliver genetically improved and high-performing nutritionally enhanced crop cultivars, with economic benefits and environmental sustainability for human well-being, which are in alignment with the United Nations goals that aim at ending hunger, achieving food security, improving nutrition and promoting sustainable agriculture globally (Eriksson et al., 2018).

In Southern Africa, crop varieties are designed, developed or deployed by the public plant breeding programmes such as the National Agriculture Research Systems (NARS), International Research Centres, the private sector or nongovernment organizations (NGOs). The NARS in collaboration with international research centres breed cultivars of food security and cash crops including cereals, root tubers, legumes and oil seed crops (Table 11.1). The public sector breeding programmes are not well developed and are often under resourced due to limited investment in plant breeding education, research and infrastructure development. Conversely, some of the private sector programmes employ state-of-the-art breeding methods and biotechnological tools to develop new cultivars for the market.

Smallholder farmers in Southern Africa have had limited access to improved modern varieties that are specifically bred for cultivation under low input production systems. Most smallholder farmers continue to grow unimproved landrace crop varieties. Landraces are inheritably low yielding but stress resilient and possess various quality traits of intrinsic value for the indigenous farmers. If their new varieties are to be adopted by smallholder farmers, plant breeders have to develop and release crop varieties that meet all the key trait requirements of these farmers and the downstream value chains and that are adapted to perform well under increasingly adverse climatic conditions caused by global climate change. The objective of this chapter is to highlight the current breeding technologies, major constraints to plant breeding programmes and to present some of the reasons why there are low levels of adoption of freshly released, modern crop varieties by smallholder farmers in Southern Africa. The chapter 
Table 11.1 National agricultural research institutes with crop improvement programmes and their major food security crops in the Southern African development community

\begin{tabular}{|c|c|c|}
\hline Country & Research institute & Major food security crop(s) \\
\hline Angola & $\begin{array}{l}\text { Agricultural Research } \\
\text { Institute of Angola }\end{array}$ & Maize, cassava \\
\hline Botswana & $\begin{array}{l}\text { Department of Agricultural } \\
\text { Research }\end{array}$ & $\begin{array}{l}\text { Maize, sorghum, millets, } \\
\text { cowpea }\end{array}$ \\
\hline $\begin{array}{l}\text { Democratic Republic } \\
\text { of the Congo }\end{array}$ & $\begin{array}{l}\text { National Agricultural } \\
\text { Research Institute }\end{array}$ & Maize \\
\hline Lesotho & $\begin{array}{l}\text { Department of Agriculture } \\
\text { Research }\end{array}$ & Maize \\
\hline Madagascar & $\begin{array}{l}\text { Horticultural Technical } \\
\text { Center of Antananarivo, } \\
\text { Biotechnology and Plant } \\
\text { Breeding Unit }\end{array}$ & Rice \\
\hline Malawi & $\begin{array}{l}\text { Department of Agricultural } \\
\text { Research Services }\end{array}$ & $\begin{array}{l}\text { Maize, cassava, pigeonpea, dry } \\
\text { bean }\end{array}$ \\
\hline Mozambique & $\begin{array}{l}\text { Agricultural Research } \\
\text { Institute of Mozambique }\end{array}$ & $\begin{array}{l}\text { Maize, sorghum, cowpea, } \\
\text { groundnut }\end{array}$ \\
\hline Namibia & $\begin{array}{l}\text { Ministry of Agriculture, } \\
\text { Water and Forestry }\end{array}$ & $\begin{array}{l}\text { Sorghum, pearl millet, cowpea, } \\
\text { Bambara groundnut }\end{array}$ \\
\hline Seychelles & $\begin{array}{l}\text { Crop Research and } \\
\text { Development Division }\end{array}$ & Cassava \\
\hline South Africa & $\begin{array}{l}\text { Agricultural Research } \\
\text { Council }\end{array}$ & $\begin{array}{l}\text { Maize, sorghum, pearl millet, } \\
\text { wheat, barley, sweet potato, } \\
\text { potato, fruits, dry bean, } \\
\text { cowpea, ground nut }\end{array}$ \\
\hline Swaziland & $\begin{array}{l}\text { Agricultural Research } \\
\text { Division }\end{array}$ & Maize, cowpea \\
\hline Tanzania & $\begin{array}{l}\text { Tanzania Agricultural } \\
\text { Research Institute }\end{array}$ & $\begin{array}{l}\text { Maize, rice, sorghum, pearl } \\
\text { millet, soya bean, cowpea, } \\
\text { potato, sweet potato, cassava }\end{array}$ \\
\hline Zambia & $\begin{array}{l}\text { Zambia Agriculture Research } \\
\text { Institute }\end{array}$ & $\begin{array}{l}\text { Maize, wheat, sorghum, pearl } \\
\text { millet, cowpea }\end{array}$ \\
\hline Zimbabwe & $\begin{array}{l}\text { Department of Research and } \\
\text { Specialists Services, Crop } \\
\text { Breeding Institute }\end{array}$ & $\begin{array}{l}\text { Maize, wheat, dry bean, ground } \\
\text { nut, cowpea, sorghum, pearl } \\
\text { millet, potato, sweet potato }\end{array}$ \\
\hline
\end{tabular}

Source: FAO, 2019

also discusses the support needs of plant breeders to guide policymakers to create enabling environments and to make investment decisions to support plant breeding as a core component of agricultural transformation.

\section{Breeding methodologies and technologies}

Various plant breeding methodologies and technologies are available, each with its advantages and limitations (Mwadzingeni et al., 2016). The public sector plant breeding programmes commonly use conventional plant breeding 
methods, including selections from local and exotic genetic resources, population improvement, pedigree breeding, hybrid breeding and backcrossing. These procedures typically require ten to 15 breeding generations to release an improved cultivar, unless complemented by the doubled haploid (DH) technology and other scientific innovations. Mutation breeding is rarely used in the region despite its potential to enhance genetic variation for biotic and abiotic stress tolerance and quality traits (Horn et al., 2016; Gwata et al., 2016). Tissue culture methods are useful in DH breeding and rapid mass production and multiplication for large-scale production.

In the region, genomic and proteomic tools are rarely used. Genomic tools have great potential in enhancing plant breeding in the region by complementing the conventional breeding methods, enhancing selection response, improving the accuracy of selection schemes and ensuring the efficient use of plant genetic resources. Gene editing is a relatively recent addition to genomics that is yet to be explored in the public sector plant breeding programmes for accelerated breeding and genetic gain. Initially, the use of genetic engineering to transform crops was seen as a technology of great promise. However, genetically modified organisms have been rejected by most countries in southern Africa, and there is a lack of enabling legislation in these countries. South Africa is the only country in southern Africa that has enabling legislation for the release and production of genetically modified crops such as maize, soybean, canola and cotton.

Conventional breeding programmes in the region have achieved notable successes in the release of various field crops (Walker et al., 2014). However, public breeding programmes need to develop high yielding and stress resilient crop varieties to serve the diverse needs of millions of smallholder farmers, value chains and local and regional markets. For instance, production of cereal crops in the region and SSA faces a serious threat caused by the recent arrival of the fall armyworm (FAW), a polyphagous insect pest that has more than 180 host plant species. Plant breeders urgently need to enhance host plant-resistance to FAW, which will provide an affordable, sustainable and environmentally friendly approach to minimizing its ongoing impact.

\section{Major constraints to regional breeding programmes and farmer access to varieties}

Public plant breeding programmes in the region are inadequately resourced and lack a critical mass of active plant breeders and breeding technicians. Often a high turnover of the relatively few plant breeding personnel negatively affects the continuity and impact of crop breeding projects and programmes. There is no harmonization of plant breeding programmes in the region. This has led to disjointed breeding programmes, which often results in multiple parallel projects. The cultivar development and release systems could be regionally consolidated to serve market needs (AGRA, 2015). Further, funding should be made available for research including into neglected crops, such as cowpea, Bambara groundnut and sorghum. 
The adoption rate of improved varieties in SSA (excluding South Africa) is below 35\%, compared with above 60\% in Asia and 80\% in South America (Walker et al., 2014). The low uptake of modern crop varieties in Africa is partly due to a lack of suitability of many new plant varieties to adequately meet the needs and preferences of the farmers and other actors such as processors, retailers and consumers in the value chain. The new varieties may also fail to meet the current and changing market demands. Therefore, the next generation of plant breeders should be trained to undertake demand-led breeding, focusing on the needs and preferences of the value chains, the marketplace and the stakeholders in the region. For instance, during the variety design phase, plant breeders should incorporate product profiles relevant to farmers and consumers to ensure high levels of adoption of the new varieties (Shimelis, 2017). This requires understanding the needs and preferences of smallholder farmers, processors, traders, retailers, consumers and other actors along the value chain of each crop.

\section{Plant breeder requirements from policymakers}

Many studies have shown that concerted and sustained plant breeding brings substantial returns on investment (ROI) with varied economic, social and environmental benefits. In the United Kingdom, plant breeding has reportedly attained an ROI as high as 40:1 (Webb, 2010). However, the sector requires adequate attention from policymakers who generally perceive plant breeding as a cost rather than an investment that gives substantial returns. Therefore, there is a need to educate policymakers in the critical need for increased investment in plant breeding capacity development and long-term investments, as summarized in Table 11.2. It is unlikely that any other area of investment will give sustained returns to match plant breeding, especially given the multiplier effect of agriculture on downstream value chains such as farmers, retailers, processors and consumers.

Table 11.2 Core requirements of plant breeders from policymakers in Southern Africa

\begin{tabular}{ll}
\hline Requirement & Reason/potential impact \\
\hline $\begin{array}{l}\text { Plant breeding education: } \\
\begin{array}{l}\text { Increased investment } \\
\text { in plant breeding } \\
\text { education }\end{array}\end{array}$ & - Training more plant breeders and breeding technicians \\
& to breed the diverse African food security crops and to \\
& serving distinct agro-ecologies and for continuity of \\
& existing breeding projects. \\
- Enhancing plant breeding programmes, including & curricula, to train the next generation of academics and \\
& demand-led plant breeders, in Africa, with expertise in \\
& African crops. \\
\hline
\end{tabular}


Plant breeding research: Increased investment in plant breeding research

Policy and regulations: Introduce or reinforce enablers for plant breeders
- Allocating research funds for plant breeding projects to develop farmer- and market-preferred and high performing cultivars for food security, enhanced livelihoods and return on investment.

- Establishing plant breeding infrastructure (e.g., breeding nurseries, greenhouses, tissue culture and seed testing laboratories, germplasm repositories, genomics and proteomics tools, phenotyping resources, automated trait measurement resources).

- Adopting demand-led plant breeding research and cultivar development based on the needs and preferences of clients and value chain and using market research, market trends and derivers, public-private sector partnership and multidisciplinary approaches.

- Promoting community-based seed systems, through seed production, processing, packaging and marketing.

- Enforcing African Union and regional legislation that provide for the harmonization of regulations on variety release, registration and marketing.

- Establishing and supporting a regional plant breeding society and networks to exchange ideas and experiences on scientific progress, technological applications and the business of plant breeding, to contribute to the training of future plant breeders, to create a forum for communication for all stakeholders in plant breeding and to promote cooperation and closer link and involvement with agriculture.

- Recognizing and rewarding plant breeders through royalty fees and award systems.

- Harmonizing regional plant breeding programmes and seed policies to minimize duplication of efforts and to save resources, to accelerate the release of new varieties or new traits at reduced cost.

- Enhancing cross-border germplasm exchange, variety release and seed systems within the same agro-ecological zones, across political borders.

- Promoting public-private partnerships to develop new traits, new inbred lines and to breed and distribute seed of new crop varieties.

- Promoting and financing small seed companies and agro-dealers, to expand the delivery system of new seed varieties and crop inputs to smallholder farmers across the entire region.

- Financing smallholder farmers to buy new and improved seeds, irrigation systems, fertilizers and crop protection resources and postharvest storage facilities.

- Financing infrastructure development to ensure that smallholder farmers have access to regional markets. 


\section{Breeding for value chains and marketplace}

Farmers are the starting point of every crop value chain. Hence, the market potential of a new crop variety is heavily dependent on the number of farmers who are interested in growing the variety. In turn, this is dependent on demand for the product in the market by consumers and processors.

Adoption rate and commercialization of modern crop cultivars in Africa can be enhanced by integrating the breeding objectives set by NARS breeders along with the needs and preferences of the clients and market in the entire value chain. This requires well-detailed and up-to-date analyses of the value chain, market and market trends of each crop. In the past, crop breeders in SSA prioritized traits based mainly on "a priority or historical assumption", that farmers need such traits without consulting them. Furthermore, plant breeders unilaterally use quantitative and qualitative selection indices and product profiles without involving clients or the needs of the market. This form of trait prioritization and product profiling rendered low adoption rates of modern crop varieties including high yielding ones. Therefore, trait prioritization and product profile should be guided by both the market demand (proportion of growers needing the variety, or the total area grown by this variety) and price differentiation (the price premium or market share of the varieties or their traits) rather than selection indices.

Demand-led variety design should follow best practices from public and private sectors in Africa and internationally for successful variety design, product profiling and market. Partnerships between the public and private plant breeding programmes is key to learn best practices and to provide customized services needed by small-scale farmers. Partnerships between the two sectors enable access to genetic resources and modern plant breeding training services and infrastructure support for the NARS breeders. It also ensures that the private partners have access to new varieties bred in the public sector, with new traits that meet the changing needs of farmers and downstream value chain. This combined with excellent breeding science and technology, vigourous awareness campaigns with farmers and customers can lead to significant gains in adoption rates and market share of new varieties developed by public sector and small seed company breeding programmes in Africa.

\section{Conclusions and recommendations}

Plant breeding can produce improved crop cultivars with economic benefits that help in achieving food and nutrition security and sustainable agriculture globally. However, in southern Africa, the public sector breeding programmes are not well developed, and they are often poorly resourced due to limited investment in plant breeding education, research and infrastructure development. The existing public breeding programmes have developed and released many crop varieties with significant yield and quality gains. However, smallholder farmers in the region have not adopted these varieties, primarily due to a 
lack of access or rejection of the new varieties because they fail to carry critical quality traits. Also, the major constraints to regional breeding programmes can be attributed partly to a lack of harmonization of plant breeding programmes, restricted movement of plant germplasm resources across national borders and insufficient active plant breeding personnel in the region. The formal seed systems in the region have not engaged with smallholder farmers in seed production, distribution and marketing. In order to increase the uptake of modern crop varieties in the region, it is critical for plant breeders to incorporate quality traits that satisfy the needs and preferences of farmers and their value chains, markets and stakeholders. Success in agricultural development through crop improvement in the region is dependent on increased investment in plant breeding education, long-term research programmes and research infrastructure development. In addition, efforts should be exerted towards the development of infrastructure and markets for farmers in the region and enhancing partnerships between the public and private plant breeding programmes.

\section{References}

Alliance for a Green Revolution in Africa (AGRA). (2015) Transforming Africa's agriculture for sustainable inclusive growth, improved livelihoods and shared prosperity: A background note. Third International Conference on Financing for Development, 13-16 July, Addis Ababa, Ethiopia, pp. 1-10.

Eriksson, D., Akoroda, M., Azmach, G., Labuschagne, M., Mahungu, N. and Ortiz, R. (2018) Measuring the impact of plant breeding on sub-Saharan African staple crops. Outlook on Agriculture 47(3): 163-180.

FAO (Food and Agriculture Organization of the United Nations). (2019) Global Partnership Initiative for Plant Breeding Capacity Building. www.fao.org/in-action/plant-breeding/ our-partners/africa.

Gwata, E.T., Shimelis, H. and Matove, P. (2016) Potential of improving agronomic attributes in tropical legumes using two mutation breeding techniques in southern Africa. In: Konvalina, P. (ed). Alternative Crops and Cropping Systems. IntechOpen Limited, London, pp. 71-85. ISBN 978-953-51-2279-1.

Horn, L., Ghebrehiwot, H.M. and Shimelis, H.A. (2016) Selection of novel cowpea genotypes derived through gamma irradiation. Frontiers in Plant Science 7: 1-13.

Mwadzingeni, L., Shimelis, H., Dube, E., Laing, M.D. and Tsilo, T.J. (2016) Breeding wheat for drought tolerance: Progress and technologies. Journal of Integrative Agriculture 15: 935-943.

Shimelis, H. (2017) New variety design and product profiling. In: Persley, G.A. and Anthony, V.M. (eds). The Business of Plant Breeding: Market-led Approaches to New Variety Design in Africa. CABI International, Wallington, UK, pp. 85-114.

Walker, T., Alene, A., Ndjeunga, J., Labarta, R., Yigezu, Y., Diagne, A., Andrade, R., Muthoni, R., De Groote, H., Mausch, K., Yirga, C., Simtowe, F., Katungi, E., Jogo, W., Jaleta, M. and Pandey, S. (2014) Measuring the Effectiveness of Crop Improvement Research in Sub-Saharan Africa from the Perspectives of Varietal Output, Adoption, and Change: 20 Crops, 30 Countries, and 1150 Cultivars in Farmers' Fields. Report of the Standing Panel on Impact Assessment (SPIA), CGIAR Independent Science and Partnership Council (ISPC) Secretariat, Rome, Italy.

Webb, D. (2010) Economic Impact of Plant Breeding in the UK. The British Society of Plant Breeders, Ely, UK. 24 pages. www.bspb.co.uk/contact-bspb.php. 